Article

\title{
Line $\times$ tester Study in Bread Wheat (Triticum aestivum L.) for Important Biochemical and Morphological Traits
}

\author{
Anand Kumar ${ }^{1}$, Lokendra Singh ${ }^{1}$, Prashant Kaushik ${ }^{2,3^{*}}$
}

1,4 Department of Genetics and Plant Breeding. Chandra Shekhar Azad University of Agriculture and Technology, Kanpur-208002, India; anandkumar002014@gmail.com

${ }^{2}$ Kikugawa Research Station, Yokohama Ueki, 2265, Kamo, Kikugawa City, Shizuoka 439-0031, Japan

3 Instituto de Conservación y Mejora de la Agrodiversidad Valenciana, Universitat Politècnica de València, 46022 Valencia, Spain

Corresponding author: prakau@doctor.upv.es

\begin{abstract}
Using line $\times$ tester analysis, the current research analyses parental genotypes and their combinations in normal conditions and identifies the genes influencing yield characteristics. In the present study, 15 diverse genotypes, including 10 lines, 5 testers, and $50 \mathrm{~F}_{1}$ hybrids, were evaluated for 13 morphological and 2 biochemical traits. A suitable location was taken to study the effect of 15 characters. The results exposed that ability mean squares were significant for all studied additive and non-additive components. In this direction, the general combining ability of PBW-343, DBW-39, K-402, K-1317, KRL-210, and K-68 were higher than the remaining parents. For morphological traits like yield, the top five crosses were described based on SCA effects, namely, HD-3086 $\times$ HD-3171, K-402 × K-9107, K-1317 × K9107, HD-2967 $\times$ K-0307 and K-402 $\times$ K-68 in F1 generation. In addition, the high value of heritability was estimated for plant height $(77.32 \%)$, spike length $(32.26 \%)$, biological yield/plant $(59.52 \%)$, and grain yield/plant $(68.76 \%)$. However, the moderate values of heritability were estimated for days to maturity $(22.78 \%)$ and phenol color reaction (18.00\%). The higher genetic advance was not found for recorded characters; however, a moderate genetic advance was recorded for grain yield per plant (13.15\%) and harvest index $(11.72 \%)$. High heritability coupled with moderate genetic advance was recorded for two characters grain yield per plant and harvest index in $F_{1}$ and $\mathrm{F}_{2}$ generations.
\end{abstract}

Keywords: Bread wheat; general combining ability; specific combining ability; heritability; genetic advance

\section{Introduction:}

Ever since human civilization took place, bread wheat has been an important cereal crop and a staple food cultivated globally [1] to fulfil the requirement of human beings [2]. Wheat consists of about $55 \%$ carbohydrates, 
$10-18 \%$ of protein and $19 \%$ of calories required for humans, and it is also used as a straw for feeding animals $[3,4]$. To meet the challenge of providing to approximate 10 billion by 2050, the wheat yield has to be double by 2050, because of which, extensive research is required to enhance the grain yield of wheat, the improvement of wheat yield may increase by applying agronomic practices, and breeding programme [5]. Continuous use of old wheat varieties threatens genetic variability, because of which, the genetic variability of the wheat has been reduced after domestication [6]. The reduction of genetic variability poses several threats to wheat crops and creates several adverse impacts like disease and insect prone. Hence, maintaining sufficient genetic diversity in breeding stock is crucial for sustainable future production $[7,8$, 9].

If sufficient genetic variability exists in a crop, no crossing programme is required, but a hybridisation programme is required to maintain or create the genetic diversity [10]. For a successful breeding programme like hybridization, suitable parents are required, and parents' performance could be checked by using a proper biometrical design. Biometrical techniques such as diallel, partial diallel and line $\times$ tester are used to check the parents' ability to transmit genes and their alleles into their progeny [11]. Estimating combining ability, nature of gene action and heritability are necessary to improve the yield and various agronomic traits, gene action, combining ability, and heritability can be measured from $F_{1}$ and $F_{2}$ generations and so on [5]. The concept of general combining ability and specific combining ability were given and defined by Sprague et al. 1942 [12]. The average effect of genes and their alleles reveals general combining ability resulting from additive gene action and their interactions, maybe fixed following generations and beneficial for developing pure lines.

In contrast, specific combining ability (SCA) variance results from nonadditive gene action that is beneficial for developing hybrid varieties [13]. Several studies show that the agronomic characters are controlled by additive and non-additive gene action [14]. GCA and SCA effects show the predominance of additive effect and non-additive effect of genes, respectively; GCA helps develop pure lines in self-pollinated crops whereas SCA helps develop hybrids in both self and cross-pollinated crops [15]. But the hybrid seed in wheat has no priority [16]. Recent studies using line $\times$ tester analysis of $F_{1}$ and $\mathrm{F}_{2}$ generations of wheat crops observed significant $(\mathrm{p}<0.05)$ positive GCA and SCA effects for yield and yield components; As we know, yield is a complex character and controlled by the polygene [17]. Hence, the wheat yield improvement programme can be assessed using a proper design line $\times$ tester $[15,17]$.

The design line $\times$ tester was used and defined by Kempthorne [18], this design provides the knowledge of the combination of genes, effects of the genotype, genetic mechanism [5], average degree of dominance, degree and direction of the dominance gene expression that controls the yield and yields contributing characters have become of more importance for the breeders for selection of the suitable parents for true development of the hybrids [19, 20]. A study suggested that inter-population improvement is more effective due 
to more divergence genes through heterotic groups than similar genetic populations [21].

Moreover, understanding the degree and relationship between yield and yields attributing characters is a relevant selection for heritability. Heritability is a good measure of the transmissibility of characters from parents to offspring and helps to decide the breeding programme for crop improvement, it is of two types viz., broad sense and narrow sense heritability [22]. Broad-sense heritability is calculated from genotypic variance to phenotypic variance, in another hand the additive genetic variance to the phenotypic variances is calculated for narrow sense heritability which requires a crossing programme in a definite fashion and becomes helpful to the selection of elite types segregating populations [23]. Robinson et al., (1949) [23] gave the classification of broad sense and narrow-sense heritability as low $(<10 \%)$, medium (10 to $30 \%)$, and high (>30\%). It has been seen in results that estimation of heritability is influenced by the methods, sample size, environments effect. The utility of heritability estimation is dependent on their reliability in predicting the gain under selection [24], in that genetic gain measures the direct and indirect selection for the effective improvement in the genetic advance [25].

There is no independent identity of genetic advance. Still, it works as a guiding factor to heritability to the plant breeders during the selection [25]. The nature of gene action is predicted by heritability and genetic advance. It provides significant knowledge of genetic variability existing in crops that is beneficial in predicting responses to the following generations' selection [24]. Johnson et al. [26] reported that genetic advance, coupled with an estimate of heritability would be of great practical based value on phenotypic expression and emphasized the use of genetic advance along with heritability, it is stated that heritability and genetic advance are two complementary concepts. In several kinds of literature, the gene action that controls grain yield in wheat was studied by several researchers [27, 28, 29]. The present study has been estimated to combining ability, nature of gene action, heritability and genetic advance for grain yield and grain yield components using line $\times$ tester design in the bread wheat [30].

\section{Material Methods:}

\subsection{Parental genotype and crossing}

The primary material was 15 diverse wheat genotypes were taken and divided into two groups viz., 10 females (lines) and 5 males (testers). Ten females and five males were sown during rabi 2018-2019 for crossing purpose following $\mathrm{L} \times \mathrm{T}$ fashion [18], at Section of Rabi cereals Nawabganj farm. All the females were crossed with five males to produce a sufficient $F_{1}$ seed of 50 crosses. The evaluation of parents, $\mathrm{F}_{1}$ and their $\mathrm{F}_{2}$ were conducted for the final trial during 2019-2020. The details of genotypes are as follows (Table 1):

Table 1. Source and details of important characters of wheat (Triticum aestivum L.) genotypes/varieties. 


\begin{tabular}{ll}
\hline Genotypes/Varieties & Source of origin \\
\hline Lines & \\
\hline HD-2733 & IARI, New Delhi \\
\hline K-1317 & CSAUA\&T, Kanpur \\
\hline DBW-88 & IIWBR, Karnal (Haryana) \\
\hline H-402 & CSAUA\&T, Kanpur \\
\hline WR-5086 & IARI, New Delhi \\
\hline HD-2967 & IARI, New Delhi \\
\hline KRL-210 & IARI, New Delhi \\
\hline PBW-343 & CSSRI, Karnal (Haryana) \\
\hline DBW-39 & PAU, Ludhiana \\
\hline Testers & IIWBR, Karnal (Haryana) \\
\hline K-8962 & \\
\hline K-9107 & CSAUA\&T, Kanpur \\
\hline K-68 & CSAUA\&T, Kanpur \\
\hline K-0307 & CSAUA\&T, Kanpur \\
\hline HD-3171 & CSAUA\&T, Kanpur \\
\hline
\end{tabular}

Development of $\mathbf{F}_{1}$ seed: All fifteen genotypes, including 10 lines (female) and 5 testers (males), have been grown during Rabi season 2018-19 for making crosses in line $\times$ tester fashion and resultant seeds of 50 hybrids $\left(\mathrm{F}_{1}\right)$ were harvested 2019-2020.

Development of $F_{2}$ seed: The half seed of each hybrid was sent for advancement at IIWBR-Regional Station, India, in an off-season nursery to obtain seed for raising $\mathrm{F}_{2}$ generation. In the final trial, each cross's half seed was procured to rase $\mathrm{F}_{1}$ generation.

\subsection{Experimental sites and agronomic practices}

The parental genotypes and obtained crosses were evaluated during 2019-2020 growing seasons. On 27 November 2019, 115 genotypes (15 parents, $50 \mathrm{~F}_{1 \mathrm{~S}}$, and $50 \mathrm{~F}_{2}$ ) were sown in a randomized complete block design (RCBD) with triplicate (three) replications at Chandra Shekhar Azad University of Agriculture and Technology's agricultural research farm in Kanpur, India. Each parent and $F_{1}$ were planted in a single row while each $F_{2}$ was planted in two rows of 3-meter-long plots and $22.5 \mathrm{~cm}$ apart, $10 \mathrm{~cm}$. Plant to plant distance was maintained. Analysis showed the soil was sandy loam to loam with $7.1 \mathrm{pH}$.. For conducting an excellent trial, all the recommended fertilizers dose nitrogen $80 \mathrm{~kg} / \mathrm{h}$, phosphorus $60 \mathrm{~kg} / \mathrm{h}$, potash $60 \mathrm{~kg} / \mathrm{h}$, zinc 15 $\mathrm{kg} / \mathrm{h}$ and boron $8 \mathrm{~kg} / \mathrm{h}$ respectively were applied and other agronomic practices such as disease protection and weed control were achieved quickly. The temperature of the field was during 2019-2020, given below.

\begin{tabular}{ll}
\hline Month & $\begin{array}{l}\text { The temperature in Fahrenheit } \\
\text { (Min./Max.) }\end{array}$ \\
\hline November & $45 / 95$ \\
\hline
\end{tabular}




\begin{tabular}{ll}
\hline December & $30 / 90$ \\
\hline January & $30 / 85$ \\
\hline February & $40 / 95$ \\
\hline March & $50 / 110$ \\
\hline April & $55 / 115$ \\
\hline May & $50 / 110$ \\
\hline
\end{tabular}

\subsection{Data acquisation}

The data was collected for different morphological and biochemical traits as given below.

\subsubsection{Days to flowering ( $75 \%)$}

The data for days to flowering was recorded as the number of days between the date of planting and 75 percent flowering based on a plot basis.

\subsubsection{Plant height $(\mathrm{cm})$}

At the maturity time, the plant base at ground level to the base of spike of main the shoot of plants was measured in $\mathrm{cm}$.

\subsubsection{Days to maturity}

It was quantified by the number of days required for selected plants to attain physiological maturity after sowing.

\subsubsection{Number of productive tillers/plant}

The total number of ear-bearing tillers per plant was counted and recorded before harvesting the crop.

\subsubsection{Flag leaf area $(\mathrm{cm}) 2$}

The flag leaf's length and width measurements were taken using the electronic instrument (area meter).

\subsubsection{Spike length $(\mathrm{cm})$}

At the maturity time, the base of the spike to tip of the pike excluding awns of main the shoot of plants were measured in $\mathrm{cm}$.

\subsubsection{Number of spikelets/spike}

The numbers of spikelets in each central shoot spike of selected plants were recorded harvest time.

\subsubsection{Number of grains/spike}

Total numbers of grains of main spike were counted in each selected plant at the time of harvesting.

\subsubsection{Biological yield/plant (gm)}


At the time of harvesting randomly selected plants for each treatment were weighed replication wise with the help of an electric balance (CompaxCx-600) for the estimation of the biological yield/plant (gm).

\subsubsection{Grain yield /plant (gm)}

All spikes of individual sampled plants for each treatment and average grain yield per plant was recorded in grams.

\subsubsection{Test weight/1000 grain weight (gm)}

One thousand grains were taken at random from the bulk produce of each treatment and weight was recorded in grams up to two decimal places replication wise using of electronic balance.

\subsubsection{Harvest index (\%)}

Harvest index is the ratio of grain yield and biological yield per plant was recorded by calculating with the help of the formula given below.

Harvest index $(\%)=$ Grain yield $/$ Biological yield $\times 100$

\subsubsection{Seed hardness}

Seed hardness or kernel hardness was determined by hand operating machine O.S.K. 20 Seed hardness tester, type E $50 \mathrm{~kg}$ capacity. To determine the seed hardness three hundred twenty normal grains from bulk seeds of each treatment were taken to record data. Each grain was placed on a sample plate, and a pressure column was put down by means of mounting the pressure till the grains get crushed. The crushed seed or grain pressure weight was noted from the scale attached to the machine. The mean of three hundred twenty seeds were taken as the final press weight in $\mathrm{kg} / \mathrm{seed}$ replication wise.

\subsubsection{Phenol color reaction}

Healthy and fully matured seeds were placed in water overnight for at least 16-20 hours. Sample of 30-40-soaked grains were put on filter paper in Petridis at a proper distance. $3 \mathrm{ml}$ phenol solution of one percent was added in each sample and covered the lid of Petridis for 3-4 hours at room temperature for the development of color. The observation was recorded based on color developed in the seeds. The color was seen by naked eye.

\subsubsection{Protein content (\%)}

The protein content (\%) of each treatment of all replications was estimated by near-infrared spectroscopy (NIRS) DS 2500 at Chandra Shekhar Azad University of Agriculture and Technology, Kanpur (Uttar Pradesh). The company name of DS-2500 was Metrohm India Private limited. The required sample of $100 \mathrm{gm}$ from each sample was taken to estimate the protein content.

\subsection{Data analysis}

Analysis of Variance (ANOVA) was conducted to detect the variability among means of each treatment using the $\mathrm{R}$ statistical software package. The 
combining ability analysis was measured according to Sprague et al. 1942 method [12]. The genetic components and related genetic parameters narrow-sense heritability and broad-sense heritability were estimated as suggested by Robinson et al. (1949) [23]. The experiment results were analyzed to study parameters among treatments, and the significance of differences was calculated using least significant differences (LSD) $\mathrm{P}<0.05$. Statistical significance was marked at $\mathrm{P}<0.05$ unless stated otherwise. Other factors such as temperature, climatic condition, topography, and soil characteristics affected the experiment.

\section{Results}

\subsubsection{Analysis of variance for combining ability:}

Analysis of variance exposed the significant variance among genotypes for grain yield and grain-related traits (Table 2). The analysis of variance for combining ability was estimated in both $\mathrm{F}_{1}$ and $\mathrm{F}_{2}$ generations. In $\mathrm{F}_{1}$ generation, significant differences were found for all the characters except days to maturity in crosses, line and in cross combination (Line $\times$ Tester). In contrast, tester effect has a significant difference for character days to maturity (Table 2). However, days to flowering and protein content of testers showed no significant differences among wheat lines (Table 2).

Table 2. ANOVA of combining ability effects for 15 characters in $F_{1}$ of line $\times$ tester cross-analysis of wheat (Triticum aestivum L.) means sum of squares.

\begin{tabular}{|c|c|c|c|c|c|c|}
\hline Source of variation & $\begin{array}{l}\text { Replica- } \\
\text { tion }\end{array}$ & Crosses & $\begin{array}{l}\text { Line Ef- } \\
\text { fect }\end{array}$ & $\begin{array}{l}\text { Tester } \\
\text { Effect }\end{array}$ & $\begin{array}{c}\text { Line } \times \text { Tester } \\
\text { Effect }\end{array}$ & Error \\
\hline Degree of freedom & 2 & 49 & 9 & 4 & 36 & 98 \\
\hline $\begin{array}{c}\text { Days to flowering } \\
(75 \%)\end{array}$ & 5.94 & $14.26^{* *}$ & $23.78^{* *}$ & 2.89 & $13.14^{* *}$ & 2.67 \\
\hline Plant height $(\mathrm{cm})$ & 0.29 & $52.99 * *$ & $228.17^{* *}$ & $41.33^{* *}$ & $10.49^{* *}$ & 0.24 \\
\hline Days to maturity & 56.6 & 77.59 & 90.52 & $163.32^{*}$ & 64.84 & 69.78 \\
\hline $\begin{array}{l}\text { Number of produc- } \\
\text { tive tillers/ Plant }\end{array}$ & 0.17 & $6.09^{* *}$ & $17.15^{* *}$ & $9.36^{*}$ & $2.96^{* *}$ & 0.06 \\
\hline Flag leaf area $(\mathrm{cm})^{2}$ & $3.81^{* *}$ & $12.37^{* *}$ & $41.93^{* *}$ & $46.24^{* *}$ & $1.22^{* *}$ & 0.26 \\
\hline Spike length $(\mathrm{cm})$ & 0.22 & $2.31^{* *}$ & $5.28^{* *}$ & $0.99^{* *}$ & $1.71^{* *}$ & 0.07 \\
\hline $\begin{array}{c}\text { Number of spikelets/ } \\
\text { Spike }\end{array}$ & $0.64^{* *}$ & $1.73^{* *}$ & $1.06^{* *}$ & $1.61^{* *}$ & $1.91^{* *}$ & 0.1 \\
\hline $\begin{array}{l}\text { Number of grains/ } \\
\text { Spike }\end{array}$ & 0.5 & $9.84^{* *}$ & $13.54^{* *}$ & $4.74^{* *}$ & $9.47^{* *}$ & 0.88 \\
\hline $\begin{array}{l}\text { Biological yield/Plant } \\
\text { (gm) }\end{array}$ & 0.17 & $116.15^{* *}$ & $203.43^{* *}$ & $440.41^{* *}$ & $58.30^{* *}$ & 0.35 \\
\hline $\begin{array}{l}\text { Grain yield/Plant } \\
(\mathrm{gm})\end{array}$ & $0.61^{* *}$ & $54.64^{* *}$ & $156.52^{* *}$ & $150.13^{* *}$ & $18.56^{* *}$ & 0.07 \\
\hline $\begin{array}{l}\text { Test weight/ } 1000 \\
\text { grain weight }(\mathrm{gm})\end{array}$ & $0.28^{*}$ & $12.41^{* *}$ & $45.16^{* *}$ & $43.99^{* *}$ & $0.71^{* *}$ & 0.072 \\
\hline Harvest index (\%) & 2.46 & $88.27^{* *}$ & $306.57^{* *}$ & $43.06^{* *}$ & $38.72^{* *}$ & 1.15 \\
\hline Seed hardness & 0.05 & $1.93^{* *}$ & $4.39^{* *}$ & $5.96^{* *}$ & $0.86^{* *}$ & 0.06 \\
\hline
\end{tabular}




\begin{tabular}{lllllll}
\hline Phenol color reaction & 0.88 & $1.14^{* *}$ & $1.60^{* *}$ & $1.11^{* *}$ & $1.02^{* *}$ & 0.49 \\
\hline Protein content $(\%)$ & 0.03 & $0.03^{* *}$ & $0.04^{* *}$ & 0.01 & $0.02^{* *}$ & 0.01 \\
\hline
\end{tabular}

$* *$, and ${ }^{*}$ indicate significance at $\mathrm{p}<0.01$, and $\mathrm{p}<0.05$, respectively.

Analysis showed significant variance among wheat genotype for grain yield and grain-related traits. The analysis of variances for combining ability indicated significant differences in $\mathrm{F}_{2}$ generation for all the characters except protein content in crosses and in Line $\times$ Tester Effect (Table 3). Days to flowering, days to maturity, phenol color reaction, and protein content of tester showed no significant difference among wheat lines (Table 3).

Table 3. ANOVA of combining ability for 15 characters in $F_{2}$ of line $\times$ tester cross-analysis of wheat (Triticum aestivum L.) mean sum of square.

\begin{tabular}{|c|c|c|c|c|c|c|}
\hline Source of variation & $\begin{array}{l}\text { Replica- } \\
\text { tion }\end{array}$ & Crosses & $\begin{array}{c}\text { Line Ef- } \\
\text { fect }\end{array}$ & $\begin{array}{l}\text { Tester } \\
\text { Effect }\end{array}$ & $\begin{array}{c}\text { Line } \times \text { Tester } \\
\text { Effect }\end{array}$ & Error \\
\hline Degree of freedom & 2 & 49 & 9 & 4 & 36 & 98 \\
\hline $\begin{array}{l}\text { Days to flowering } \\
(75 \%)\end{array}$ & 5.28 & $16.91^{* *}$ & $34.11^{*}$ & 3.99 & $14.04^{* *}$ & 3.83 \\
\hline Plant height $(\mathrm{cm})$ & 0.62 & $112.38^{* *}$ & $150.49^{* *}$ & $144.71^{* *}$ & $99.26^{* *}$ & 3.51 \\
\hline Days to maturity & 3.38 & $11.85^{* *}$ & $33.85^{* *}$ & 1.11 & $7.54^{*}$ & 4.72 \\
\hline $\begin{array}{l}\text { Number of produc- } \\
\text { tive tillers/ Plants }\end{array}$ & 0.21 & $5.63^{* *}$ & $14.29^{* *}$ & $10.99^{*}$ & $2.87^{* *}$ & 0.08 \\
\hline Flag leaf area $(\mathrm{cm})^{2}$ & 0.39 & $54.08^{* *}$ & $48.09^{* *}$ & $63.78^{* *}$ & $54.50^{* * *}$ & 0.23 \\
\hline Spike length $(\mathrm{cm})$ & 0.2 & $1.59^{* *}$ & $2.68^{* *}$ & $1.02^{* *}$ & $1.37^{* *}$ & 0.14 \\
\hline $\begin{array}{l}\text { Number of spikelets/ } \\
\text { Spike }\end{array}$ & 0.29 & $1.77^{* *}$ & $2.13^{* *}$ & $0.81^{* *}$ & $1.79^{* *}$ & 0.16 \\
\hline $\begin{array}{c}\text { Number of grains/ } \\
\text { Spike }\end{array}$ & 0.51 & $5.26^{* *}$ & $8.47^{* *}$ & $7.30^{* *}$ & $4.23^{* *}$ & 1.54 \\
\hline $\begin{array}{l}\text { Biological yield/Plant } \\
\text { (gm) }\end{array}$ & $2.53^{* *}$ & $111.68^{* *}$ & $198.46^{* *}$ & $428.29^{* *}$ & $54.80^{* *}$ & 0.5 \\
\hline $\begin{array}{l}\text { Grain yield/Plant } \\
\text { (gm) }\end{array}$ & 0.07 & $54.58^{* *}$ & $156.60^{* *}$ & $147.57^{* *}$ & $18.74^{* *}$ & 0.05 \\
\hline $\begin{array}{l}\text { Test weight/ } 1000 \\
\text { grain weight }(\mathrm{gm})\end{array}$ & 0.01 & $16.11^{* *}$ & $24.84^{* *}$ & $2.79^{* *}$ & $15.40^{* *}$ & 0.02 \\
\hline Harvest index (\%) & $5.18^{*}$ & $87.47^{* *}$ & $318.06^{* *}$ & $22.99 * *$ & $36.99 * *$ & 1.19 \\
\hline Seed hardness & 0.15 & $6.95^{* *}$ & $17.68^{* *}$ & $2.58^{* *}$ & $4.75^{* *}$ & 0.14 \\
\hline Phenol color reaction & 0.32 & $1.20^{* *}$ & $3.31^{* *}$ & 0.36 & $0.77^{*}$ & 0.47 \\
\hline Protein content $(\%)$ & 0.01 & 0.01 & $0.03^{*}$ & 0.01 & 0.01 & 0.01 \\
\hline
\end{tabular}

**, and ${ }^{*}$ indicate significance at $\mathrm{p}<0.01$, and $\mathrm{p}<0.05$, respectively.

The female component was significant for flag leaf area $(\mathrm{cm})^{2}$ and test weight/1000 grain weight (gm) in $\mathrm{F}_{1}$ generation, and ratio of male component was significant for days to flowering in $\mathrm{F}_{1}$ generation (Table S1) (Supplementary table). In $\mathrm{F}_{2}$, the male component was substantial for days to maturity and test weight/1000 grain weight. Additionally, the male and female components were significant for all characters except days to flowering, days to maturity and protein content in both $\mathrm{F}_{1}$ and $\mathrm{F}_{2}$ generation, while phenol color reaction in $\mathrm{F}_{2}$ generation only (Table S1). Estimation of $\delta^{2} \mathrm{~g}$ was less than their 
respective $\delta^{2} \mathrm{~s}$ for all the characters in both generations except flag leaf area $(\mathrm{cm}) 2$, test weight/1000 grain weight ( $\mathrm{gm})$ in $\mathrm{F}_{1}$ generation, indicating the importance of non-additive gene action (Table S1). The ratio of $\delta^{2} \mathrm{~g} / \delta^{2} \mathrm{~s}$ has been estimated as less than unity for all the characters in both $\mathrm{F}_{1}$ and $\mathrm{F}_{2}$ generations (Table S1). The values of the average degree of dominance expressed as $\left[\delta^{2} \mathrm{~s} / \delta^{2} \mathrm{~g}\right]^{0.5}$ was more than unity for all characters in both $\mathrm{F}_{1}$ and $\mathrm{F}_{2}$ generations (Table S1).

The general and specific combining ability components have shown significant differences for all the characters except, days to flowering (75\%), days to maturity, phenol color reaction, and protein content reflected the predominance of additive gene action in both $\mathrm{F}_{1}$ and $\mathrm{F}_{2}$ generation (Table-S1).

\subsubsection{General combining ability (GCA)}

Genetic variability and mean performance of parents and their crosses are a good source of genotypic evaluation. However, parents with highest means could not be necessary to transmit traits/superior performance in their progeny/hybrids. To assess the performance of parents and their combination, general and specific combining ability were estimated. In this experiment, the results exposed that none of the parents were found to be a good general combiner for all the fifteen characters (Table S2). The estimates obtained for the GCA effect has been given in table S2. In the case of biochemical traits, the GCA value of the parents was not significant for phenol color reaction except PBW-343 and DBW-39 and none of the parents was a good general combiner for protein content (\%) (Table S2). Among the 13 morphological characters, the best general combiner was K-402 for 9 morphological traits such as days to flowering, number of productive tillers per plant, flag leaf area, spike length, biological yield/plant(gm), grain yield/plant(gm), test weight/1000 grain weight (gm), harvest index (\%), seed hardness. K-1317 and $\mathrm{K}-68$ were good general combiners for 7 morphological traits in $\mathrm{F}_{1}$ ((Table S2). This was a rare combination that general combiner WR-544 did not show GCA effects for any morphological characters in $\mathrm{F}_{1}$ (Table 5). However, HD3171, WR-544, K-0307, DBW-88 and HD-2967 were found to be as good general combiners for seed yield per plant based on mean performance and GCA effects for important yield contributing characters (Table S2).

In $F_{2}$, the results exposed that none of the parents was a good general combiner for all the fifteen biochemical and morphological characters (Table S3). The estimates obtained for the GCA effect have been given in Table S3. In the case of biochemical traits, the GCA value of all parents was not significant for phenol color reaction except PBW-343 and DBW-39. KRL-210 was not a good general combiner for protein content (\%) (Table S3). Among of the 13 morphological characters, the best general combiner was K-1317 for 8 characters such as plant height $(\mathrm{cm})$, number of productive tillers/plant, number of spikelets/spike, biological yield/plant(gm), grain yield/plant(gm), test weight/1000 grain weight (gm), harvest index (\%) and seed hardness. K-402 was a good general combiner for 8 morphological traits in $\mathrm{F}_{2}$ (Table S3). The general combiner WR-544 showed GCA effects for Flag leaf area $(\mathrm{cm})^{2}$ in $\mathrm{F}_{2}$ (Table S3). 


\subsubsection{Specific combining ability effects}

Specific combining ability measures parental lines' performance in a particular specific combination. The specific combining ability of 50 crosses for grain yield and grain yield traits of $\mathrm{F}_{1}$ are presented in Table S4. None of the crosses showed significantly positive SCA for all biochemical and morphological traits. Among 50 crosses, the top five crosses were described based on SCA effects namely HD-3086 $\times$ HD-3171, K-402 × K-9107, K-1317 × K-9107, HD-2967 $\times$ K-0307 and K-402 $\times$ K-68 for grain yield (Table S4). Among the biochemical traits, the highest fluctuations for SCA were recorded for phenol color reaction in the crosses K-402 $\times$ K-0307 andWR- $544 \times \mathrm{K}-68$, none of the crosses were found significant for protein content. Among all the 13 morphological traits, based on SCA effect of the common cross combination, K-402 × K-9107 was found good specific combiner for three characters in $\mathrm{F}_{1}$ (Table S4). HD-2733 $\times$ HD-3171 was found good specific combiners for two characters, namely spike length and seed hardness. DBW-88 $\times$ K-68 was found to be a good specific combiner for two characters: number of grains/spike and biological yield/plant. HD-2967 × K-0307 and HD-3086 $\times$ HD-3171 were found good specific combiners for two characters namely biological yield/plant and grain yield/plant (Table S4). DBW-39 $\times$ K-68 and PBW-343 $\times$ K-68 were found good specific combiners for spike length. K-402 $\times$ HD-3171and HD-2733 $\times$ K0307 were found good specific combiners for number of spikelets/spike. HD$2967 \times$ K-9107 was found good specific combiner for number of grains/spike (Table S4). WR-544 $\times$ K-8962 was found good specific combiner for biological yield/plant. K-1317 $\times$ K-9107 and K-402 $\times$ K-68 were found good specific combiners for grain yield/plant. PBW-343 $\times$ HD-3171, DBW-39 $\times$ K-9107 and HD$2967 \times$ K-68 were found good specific combiners for harvest index. K-402 $\times$ K-0307, HD-3086 × K-68 and DBW-88 × K-8962 were found good specific combiners for phenol color reaction and K-1317 $\times$ K-68 was found for protein content (Table S4).

\subsection{Heritability and genetic advance}

The result of the present investigation indicated that the highest value of heritability was estimated for plant height $(\mathrm{cm})(77.32 \%)$, number of productive tillers/ plant $(54.25 \%)$, flag leaf area $(\mathrm{cm})^{2}(90.49 \%)$, spike length $(\mathrm{cm})$ $(32.26 \%)$, biological yield/plant (gm) $(59.52 \%)$, grain yield/plant (gm) $(68.76 \%)$, test weight/1000 grain weight (gm) $(94.34 \%)$, harvest index $(\%)$ $(54.32 \%)$ and seed Hardness (61.08\%) in $\mathrm{F}_{1}$ (Table 4$)$. While in $\mathrm{F}_{2}$, high value of heritability was estimated for days to maturity (30.98\%), number of productive tillers/ plant (53.84\%), biological yield/plant (gm) $(60.35 \%)$, grain yield/plant (gm) (68.37\%), harvest index (\%) (54.83\%), seed Hardness $(35.92 \%)$, phenol color reaction $(31.86 \%)$ (Table 4$)$. In addition, the moderate value of heritability was estimated for days to maturity (22.78\%), number of spikelets per spike (14.14\%), number of grains per spike (18.95\%) and phenol color reaction (18.00\%) in $\mathrm{F}_{1}$ (Table 4). While in $\mathrm{F}_{2}$, the moderate value of heritability was estimated for plant height $(27.97 \%)$, flag leaf area $(21.40 \%)$, spike length $(24.94 \%)$, number of spikelets per spike $(15.78 \%)$, number of grains per spike $(18.93 \%)$ and test weight $(19.27 \%)$ (Table 4$)$. Whereas low value of 
heritability was estimated for days to flowering $(2.00 \%)$ and protein content $(3.50 \%)$ in both the generations (Table 4$)$.

High genetic advance was not found for recorded characters. However, a moderate genetic advance was recorded for plant height (10.72\%), biological yield per plant $(23.15 \%)$, grain yield per plant $(13.15 \%)$ and harvest index $(11.72 \%)$ in $\mathrm{F}_{1}$ generation (Table 4 ) and plant height (13.68\%), biological yield per plant $(22.42 \%)$, grain yield per plant $(12.51 \%)$ and harvest index $(11.58 \%)$ in $\mathrm{F}_{2}$ generation (Table 4).

Table 4. Heritability (narrow sense) and genetic advance for 15 characters in $\mathrm{F} 1$ and $\mathrm{F}_{2}$ generations of wheat (Triticum aestivum L.).

\begin{tabular}{lllll}
\hline \multirow{2}{*}{ Characters } & \multicolumn{2}{l}{ Heritability (\%) } & \multicolumn{2}{l}{ Genetic Advance (\%) } \\
\cline { 2 - 5 } & $\mathbf{F}_{\mathbf{1}}$ & $\mathbf{F}_{\mathbf{2}}$ & $\mathbf{F}_{\mathbf{1}}$ & $\mathbf{F}_{\mathbf{2}}$ \\
\hline Days to flowering (75\%) & 2.00 & 9.97 & 2.38 & 3.45 \\
\hline Plant height (cm) & 77.32 & 27.97 & 10.72 & 13.68 \\
\hline Days to maturity & 22.78 & 30.98 & 0.70 & 2.31 \\
\hline Number of productive tillers/ plant 54.25 & 53.84 & 4.02 & 3.42 \\
\hline Flag leaf area (cm) & 90.49 & 21.40 & 4.51 & 8.17 \\
\hline Spike length (cm) & 32.26 & 24.94 & 2.28 & 1.80 \\
\hline Number of spikelets/spike & 14.14 & 15.78 & 2.26 & 1.74 \\
\hline Number of grains/spike & 18.95 & 18.93 & 5.10 & 3.99 \\
\hline Biological yield/plant (gm) & 59.52 & 60.35 & 23.15 & 22.42 \\
\hline Grain yield/plant (gm) & 68.76 & 68.37 & 13.15 & 12.51 \\
\hline Test weight/1000 grain weight (gm) 94.34 & 19.27 & 4.76 & 5.28 \\
\hline Harvest index (\%) & 54.32 & 54.83 & 11.72 & 11.58 \\
\hline Seed Hardness & 61.08 & 35.92 & 1.71 & 3.08 \\
\hline Phenol color reaction & 18.00 & 31.86 & 0.57 & 0.63 \\
\hline Protein content (\%) & 3.50 & 5.04 & 1.21 & 1.23 \\
\hline
\end{tabular}




\section{Discussion}

The crops self-pollinated like wheat has many valuable agronomic and quality traits [31]. The grain yield is one of the most important traits and the object of the plant breeders is to improve grain yield traits [32]. Improvement of the grain yield can be done by applying agronomic practices and a hybridization programme [33]. A hybridization programme is done when variability does not exist in crops; then, the main objective of the plant breeders would be to create variability [34]. However, the created inter-and intraspecific variation conditions genetic analysis and selection processes [5]. Analysis of variance showed significant variation among genotypes and their combinations [35]. In this context, our results exposed that there was considerable variation among the parental genotypes for different traits in experiments were conducted. This variation was better manifested in the hybrids, as they were significantly different for all measured traits. Significant genetic variability indicates that parents and their combination can be used for further improvement [10].

For the testers effect, character days to maturity of lines $\times$ testers in $\mathrm{F}_{1}$ s did not show significant variation. In addition, the characters days to flowering (75\%), days to maturity, phenol color reaction, protein content $(\%)$ of testers effect did not expose significant variation. The character protein content of lines $\times$ testers effects in $F_{2}$, which showed no significant differences between parents and their combination. Even though some testers, lines and their combination show significant variation but some not, amongst the testers, differences between extreme average value, for some combinations the mean values of studied traits had specified as close to the parent values and for some of the combinations it was higher compared to these of the parents have shown that the heterotic effect appeared highly in point of such traits in these combinations [30].

The progress of breeding programs is depending predominantly on the precision identification of used parents [36, 37, 38] Numerous cycles of crossing and selection among used parents and their progenies are needed to improve gene pyramiding and to fix promising recombinants $[39,40]$. In the current study, the combining ability analysis revealed that both GCA and SCA effects play an indispensable role in controlling grain yield and its associated traits [5]. The female and male components were significant for flag leaf area $(\mathrm{cm})^{2}$, test weight/1000 grain weight $(\mathrm{gm})$ and days to flowering in $\mathrm{F}_{1}$ generation respectively, while other traits were not. Additionally, the male and female components were significant for all characters except flowering, days to maturity and protein content in both $F_{1}$ and $F_{2}$ generation. The main reason for this was that the flag leaf is the first vegetable leaf that appears on the surface of the soil at the base of the spike holder. Scientific research has shown that it contributes effectively to the transfer of carbohydrates to the grains formed in the spike and transfers an amount (75\%) of the manufactured materials from the source to the downstream [41] and test weight/1000 grain weight (gm) is one of the important characteristics and it is one of the main components of the outcome grain, It is an indication of the efficacy of the downstream in assimilating source products at the seed storage sites [41]. Estimation of $\delta^{2} \mathrm{~g}$ was less than their respective $\delta^{2} \mathrm{~s}$ for all the characters indicated the importance of non-additive gene action. The values of the average degree of dominance expressed as $\left[\delta^{2} \mathrm{~s} / \delta^{2} \mathrm{~g}\right]^{0.5}$ is more than unity for all characters in both $F_{1}$ and $F_{2}$ generations. It has been suggested by scientific research that additive and nonadditive gene action controls the traits $[42,43]$. These findings are in agreement with earlier findings reported by Valério et al., 2009 [44, 45, 46].

[36]. The different estimates obtained in $\mathrm{F}_{1}$ and $\mathrm{F}_{2}$ generation grown in the same environment may be attributed to the restricted sampling in the total variability in $\mathrm{F}_{2}$ or may be due to linkage [47]. It is reported that if there was the preponderance of repulsion phase linkage, non-additive variance could increase (i.e., additive to non-additive) [44, 45, 
46]. However, characters days to flowering (75\%), number of productive tillers/plant, number of grains/spike, biological yield/plant, grain yield/plant, harvest index (\%), seed hardness and phenol color reaction reflected the predominance of additive gene action in the $\mathrm{F}_{2}$ generation. The difference in the nature of gene action results may be due to variation in population size, sampling error, nature of material and environmental conditions in which the experiment was conducted, and method of analysis used [48]. In general, most of the parents maintained their superiority in both generations and showed comparable estimates of GCA effects, which may be due to genotypic differences among the plants $[49,50,51]$.

Usually, for a self-pollinated crop like wheat, hybrid has no significance but study of segregating population for specific combining ability has a significant role [35]. (Grain yield is a function of its components that are directly involved in yield fluctuations [52]. The General combining ability of PBW-343, DBW-39, K-402, K-1317, KRL-210, and K-68 was higher than the remaining parent [35]. These lines showed the superiority over other lines for yield-related traits like flag leaf area $\left(\mathrm{cm}^{2}\right)$, spikelets per spike, number of grains/spike, biological yield/plant(gm), grain yield/plant(gm), test weight/1000 grain weight (gm), harvest index (\%), seed hardness. Fasahat et al. [37] suggested that these observations of parents could be used in generating a segregating population. However, the GCA alone is not a sufficient approach for improving the grain yield because the parents have more similarity [35].

Even though, SCA does not provide sufficient yield improvements in crop like wheat, productive crosses are expected to generate transgressive segregants to be used as potent homozygous lines [53]. Therefore, in such conditions, the SCA approach will be applied to improve the grain yield and provide an opportunity to select superior combinations. For morphological traits like yield, the top five crosses were described based on sca effects, HD-3086 $\times$ HD-3171, K-402 × K-9107, K-1317 × K-9107, HD-2967 × K-0307 and K-402 $\times$ K-68. The higher magnitude of SCA effects displays non-additive gene action's predominant role. In the present study, it was observed that the best combination had involved different combinations of high $\times$ high, high $\times$ low, low $\times$ low general combiner for the characters studied [54]. This suggests that good cross combinations are not always obtained between high $\times$ high general combiner [55]. This might be probably due to the presence of a dominant and epistatic type of gene interaction [52]. Similarly, Kamara et al., 2021, [10] reported results, which states that non-additive gene action was predominant for characters studied in wheat. The positive F value for most studied traits hinted that the frequency of dominant alleles was greater than the recessive ones in the parents [10, $45,46]$. In addition, we selected the parents were distinctive from each other because it allowed us to examine how the cross combinations were different [56].

In addition, the observed low to moderate narrow sense heritability values for all traits are associated with non-additive gene action as in cases like the current study [57]. This suggested that selection could be less effective in the segregated generations. Consequently, recurrent and pedigree selection in advanced generations could be recommended for improving studied traits. These findings coincide with the results obtained by Sareen et al. 2018 who situated moderately to low narrow-sense heritability values for yield traits [58].

\section{Conclusion:}

Wheat improvement programme would greatly benefit from the exploitation of philosophy and technique involve in nature and magnitude of gene effects, heritability, and genetic advance for yield components. In the present study, genetic components' estimates reflect the variable expression from character to character and generation to generation. Highly genetic variations were detected among parents and their F1 hybrids for all measured traits under optimal conditions. It is suggested that studied parents may be 
utilized in multiple crossing programs. Inter mating population involving all possible crosses among themselves subjected to line $\times$ tester selective mating to offer maximum promise in breeding for high yielding varieties. In most of the cases, if the characters are unidirectionally controlled by a set of alleles with predominant additive effects, the selection of parents, based on per se performance may be adequate, but in some cases, the choice of parents, on the basis phenotypic performance alone may be misleading as phenotypically superior lines may yield poor recombinants in segregating populations.

Supplementary Materials: The following supporting information can be downloaded at: www.mdpi.com/xxx/s1, Table S1: Estimation of genetic components, their ratio [๑2g/@2s]

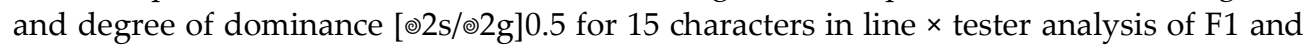
F2 generations in wheat (Triticum aestivum L.).,Table S2: Estimates of general combining ability (gca) effects of parents in line $\times$ tester cross analysis for 15 characters in $\mathrm{F}_{1}$ generation of wheat (Triticum aestivum L.)., Table S3: Estimates of general combining ability (gca) effects of parents in line $\times$ tester cross analysis for 15 characters in $F_{2}$ generation of wheat (Triticum aestivum L.) and Table S4: Estimation of specific combining ability (SCA) effects of 15 characters in $\mathrm{F}_{1}$ generation of wheat (Triticum aestivum L.).

\section{Author Contributions}

A.K., L.S. and P.K. conceived of and designed the project; A.K. and L.S. performed the experiments and did the data analysis; P.K. supervised the study; A.K., L.K. and P.K. wrote the paper; P.K. checked and corrected the final draft. Both authors have read and agreed to the published version of the manuscript.

\section{Funding}

This research received no external funding.

Institutional Review Board Statement

Not applicable.

Informed Consent Statement

Not applicable.

Data Availability Statement

Not applicable.

\section{Acknowledgments}

The authors are thankful to the anonymous reviewers for their careful read.

\section{Conflicts of Interest}

The authors declare that no conflict of interest exists.

\section{References:}

1. FAOSTAT. Food and Agriculture Organization of the United Nations. Statistical Database. Available online: http://www.fao. org/home/en/ (accessed on 13 May 2021).

2. Istipliler, D.E; Ilker, F.A.; Tonk, G.; Civi, T. M. Line x tester analysis and estimating combining abilities for yield and some yield components, in breed wheat. Turkish J. Field Crop. 2015, 20, 72-77.

3. Shewry, P.R.; Hey, S.J. The contribution of wheat to human diet and health. Food Energy Secur. $2015,4,178-202$.

4. Joye, I.J. Dietary Fibre from Whole Grains and Their Benefits on Metabolic Health. Nutrients 2020, $12,3045$.

5. Mohammadi, M.; Mirlohi, A.; Majidi, M.M.; Kartalaei, E.S. Emmer wheat as a source for trait improvement in durum wheat: a study of general and specific combining ability. Euphytica, 2021, 217, 1-20.

6. Fu, Y.B.; Somers, D.J. Genome-wide reduction of genetic diversity in wheat breeding. Crop Sci. 2009, 49, 161-168

7. Henkrar, F.; El-Haddoury, J.; Ouabbou, H. Genetic diversity reduction in improved durum wheat cultivars of Morocco as revealed by microsatellite markers. Sci Agric. 2016, 73:134-141.

8. Bassi, F.M.; Nachit, M.M. Genetic gain for yield and allelic diversity over 35 years of durum wheat breeding at ICARDA. Crop Breed Genet Genomics. 2019, 1, 1-19. 
9. Xynias, I.N.; Mylonas, I.; Korpetis, E.G. Durum wheat breeding in the Mediterranean region: current status and future prospects. Agronomy 2020, 10, 1-27.

10. Kamara, M.M.; Ibrahim, K.M.; Mansour, E.; Kheir, A.; Germoush, M.O.; El-Moneim, A.; Motawei, M.I.; Alhusays, A.Y.; Farid, M.A.; Rehan, M. Combining Ability and Gene Action Controlling Grain Yield and Its Related Traits in Bread Wheat under Heat Stress and Normal Conditions. Agronomy, 2021, 11, 1450.

11. Mohammed, M.I. Half Diallel among Genotypes of Wheat Bread for Yield its Components Triticum aestivium L., 2020, 7413-.7422.

12. Sprague, G.F.; Tatum, L.A. General vs. Specific Combining Ability in Single Crosses of Corn 1 . Agronomy Journal $1942,34,676$ 923-932,

13. Parveen, N.; Iqbal, M.; Tahir, M.; Aleem, S.; Aslam, R.; Amin, E.; Cheema, K.L.; Khan, A.S. Assesment of heritable variation and best combining genotypes for grain yield and its attributes in bread wheat. Amer. J. Agri. Res. 2019, 4, 19

14. Adel, M.M.; Ali, E.A. Gene Action and Combining Ability in a Six Parent Diallel Cross of. Asian Journal of crop science, 2013, 5, 14-23.

15. Al-Naggar, A.M.M.; Shabana, R.; Abd El-Aleem, M.M.; El-Rashidy Zainab, A. Diallel analysis of wheat grain protein content and yield in F1 and F2 generations under contrasting nitrogen conditions. Am J Agric Biol Sci. $2015,1,12-29$.

16. Jadoon, S. A.; Mohammad, F.; Ullah, H.; Khalil, I. H. Gene action for pre and post harvest traits in F2 wheat populations. QScience Connect, 2013, 11, 1-5

17. Farshadfar, E.; Ghaderi, A.; Yaghotipoor, A.N. Diallel analysis of physiologic indicators of drought tolerance in bread wheat (Triticum aestivum L.). Agric. Comm. 2014, 2, 1-7.

18. Kempthorne, O. An introduction to genetic statistics. John Wiley and sons, New York, NY, USA; 1957

19. Kumar, V.; Maloo, S.R. Heterosis and combining ability studies for yield components and grain protein content in bread wheat (Triticum aestivum L.) Indian J Genet Plant Breed. 2011, 71, 363-366.

20. Mohammad, A.K.; Muhammad, S.; Tawee, A.l. Study of genetic parameters and cluster analysis for new genotypes of bread wheat (Triticum aestivum L.). Plant Archives Journal. 2020, 20, 2396-2402.

21. Reif, J.C.; Gowda, M.; Maurer, H.P.; Longin, C.F.H.; Korzun, V.; Ebmeyer, E.; Bothe, R.; Pietsch, C.; Würschum, T. Association mapping for quality traits in soft winter wheat. Theor. Appl. Genet. 2011, 122, 961-970.

22. Falconer, D.S. Introduction of Quantitative Genetics, Longman Inc. Ltd., New York 1981.

23. Robinson, H.F.; Comstock, R.E.; Harvey, P.H. Estimate of heritability and degree of dominance in corn. Agron J. $1949,41,353-359$

24. Chowdhary, M.A.; Sajad, M.; Ashraf, M.I. Analysis of combining ability of metric traits in bread wheat (Triticum aestivum L.). Journal of Agricultural Research. 2007, 45, 11-18.

25. Thungo, Z.; Shimelis, H.; Odindo, A.; Mashilo, J. Genetic gain for agronomic, physiological, and biochemical traits and quality attributes in bread wheat (Triticum aestivum L.): a meta-analysis. Euphytica, 2021, 217, 1-33.

26. Johnson, H.W.; Robinson, H.F.; Comstock, R.E. Estimates of genetic and Environmental variability in Soybeans, Agron. J. 1955, 47, 314-318.

27. Titan, P.; Meglic, V.; Iskra, J. Combining ability and heterosis effect in hexaploid wheat group. Genetika. 2012, 44, 595-609.

28. Abro, S.A.; Baloch, A.W.; Baloch, G.A.; Soomro, A.A.; Jogi, Q.; Ali, M. Line $\times$ tester analysis for estimating combining ability in F1 hybrids for bread wheat. Pure. Appl. Biol. Sci. 2016. 5, 647-652.

29. Ali, S.; khan, N.U.; Gul, S.; Goher, R.; Naz, I.; Khan, S.A.; Ali, N.; Saeed, M.; Hussain, I.; Khan, S.M.; Ali, I. Heterotic effects for yield related attributes in F1 population of maize. Pak. J. Bot. 2019, 51, 1675-1686. 
30. Askander, H.S.; Salih, M.M.; Altaweel, M.S. Heterosis and combining ability for yield and its related traits in bread wheat (Triticum aestivum 1.). plant cell biotechnology and molecular biology, 2021, 46-53.

31. Zaharieva, M.; Negash, G.A., Amin, H.; Satish, C.; Philippe, M. "Cultivated emmer wheat (Triticum dicoccon Schrank), an old crop with promising future: a review." Genet. Resour. Crop Evol. 57, 6, 937-962.

32. Gimenez, K.; Blanc, P.; Argillier, O.; Pierre, J.B.; Le Gouis, J.; Paux, E. Dissecting Bread Wheat Heterosis through the Integration of Agronomic and Physiological Traits. Biology, 2021, 10, 907.

33. Omara, R.I.; Shahin, A.A.; Ahmed, S.M.; Mostafa, Y.S.; Alamri, S.A.; Hashem, M.; Elsharkawy, M.M. Wheat Resistance to Stripe and Leaf Rusts Conferred by Introgression of Slow Rusting Resistance Genes. Journal of Fungi 2021, $7,622$.

34. Elango, D.; Sandoya, G.; Chopra, S. Techniques and Tools of Modern Plant Breeding. In Plant Biotechnology, 2021, 17-26). Springer, Cham.

35. Riaz, M.W.; Yang, L.; Yousaf, M.I.; Sami, A.; Mei, X.D.; Shah, L.; Rehman, S.; Xue, L.; Si, H.; Ma, C. Effects of Heat Stress on Growth, Physiology of Plants, Yield and Grain Quality of Different Spring Wheat (Triticum aestivum L.) Genotypes. Sustainability 2021, 2972.

36 Salem, T.; Rabie, H.; Mowafy, S.; Eissa, A.; Mansour, E. Combining ability and genetic components of egyptian cotton for earliness, yield, and fiber quality traits. SABRAO J. Breed. Genet. 2020, 52, 369-389

37. Fasahat, P.; Rajabi, A.; Rad, J.; Derera, J. Principles and utilization of combining ability in plant breeding. Biom. Biostat. Int. J. 2016, 4, 1-24.

38. Desoky, E.-S.M.; Mansour, E.; Yasin, M.A.; El Sobky, E.-S.E.; Rady, M.M. Improvement of drought tolerance in five different cultivars of Vicia faba with foliar application of ascorbic acid or silicon. Span. J. Agric. Res. $2020,18,16$.

39. Joshi, R.K.; Nayak, S. Gene pyramiding-A broad spectrum technique for developing durable stress resistance in crops. Biotechnol. Mol. Biol. Rev. 2010, 5, 51-60.

40. Desoky, E.-S.M.; Mansour, E.; Ali, M.M.A.; Yasin, M.A.T.; Abdul-Hamid, M.I.E.; Rady, M.M.; Ali, E.F. Exogenously used 24- epibrassinolide promotes drought tolerance in maize hybrids by improving plant and water productivity in an arid environment. Plants 2021, 10, 354

41. Abbass, D.M.; Al-Layla, M.G.; Al-Hamdani, Z.B. Estimation of heritability and expect genetic improvement and expected in Durum Wheat (Triticum durum Desf.). Journal of University of Shanghai for Science and Technology, 2020, 22, 2192-2200.

42. Hassan, G.; Mohammad, F.; Afridi, S.S; Khalil, I.H. Combining ability in the $\mathrm{f} \sim 1$ generations of diallel cross for yield and yield components in wheat. Sarhad J. Agric. 2007, 23, 937.

43. Singh, M.K.; Sharma, P.K.; Tyagi, B.S.; and Singh, G. Combining ability analysis for yield and protein content in bread wheat (Triticum aestivum L.). Indian J. Agric. Sci, 2014, 84, 328-336.

44. Çifci, E.A.; Yagdi, K. The research of the combining ability of agronomic traits of bread wheat in F1 and F2 generations. Journal of Agricultural Faculty of Uludag University, 2010, 24, 85-92.

45. Akram, Z.; Ajmal, S.U.; Khan, K.S.; Qureshi, R.; Zubair, M. Combining ability estimates of some yield and quality related traits in spring wheat (Triticum aestivum L.). Pak. j. bot. 2011, 43, 221-231.

46. Valério, I.P.; de Carvalho, F.; de Oliveira, A.C.; de Souza, V.Q.; Benin, G.; Schmidt, D.; Ribeiro, G.; Nornberg, R.; Luch, H. Combining ability of wheat genotypes in two models of diallel analyses. Crop Breed. and App. Biotech. 2009, 9.

47. Kumar, J.; Kumar, A.; Kumar, M.; Singh, S.K.; Singh, L. Inheritance pattern of genes for morpho-physiological and yield traits in wheat (Triticum aestivum L.). Cereal research communications, 2019, 47, 191-204.

48. Mia, M.S.; Liu, H.; Wang, X.; Lu, Z.; Yan, G. Response of wheat to post-anthesis water stress, and the nature of gene action as revealed by combining ability analysis. Crop and Pasture Science, 2017, 68, 534-543. 
49. Boeven, P.H.; Zhao, Y.; Thorwarth, P.; Liu, F.; Maurer, H.P.; Gils, M.; Schachschneider, R.; Schacht, J.; Ebmeyer, E.; Kazman, E.; Mirdita, V. Negative dominance and dominance-by-dominance epistatic effects reduce grain-yield heterosis in wide crosses in wheat. Science Advances, 2020, 6, 4897.

50. Adhikari, A.; Ibrahim, A.M.; Rudd, J.C.; Baenziger, P.S.; Sarazin, J.B. Estimation of heterosis and combining abilities of US winter wheat germplasm for hybrid development in Texas. Crop Science, 2020, 60, 788-803.

51. Semahegn, Y.; Shimelis, H.; Laing, M.; Mathew, I. Combining ability of bread wheat genotypes for yield and yieldrelated traits under drought-stressed and non-stressed conditions. South African Journal of Plant and Soil, 2021, 38, 171179.

52. Mwadzingeni, L.; Shimelis, H.; Tsilo, T.J. Combining ability and gene action controlling yield and yield components in bread wheat (Triticum aestivum L.) under drought-stressed and nonstressed conditions. Plant Breeding, 2018, 137, 502-513.

53. Fellahi, Z.E.A.; Hannachi, A.; Bouzerzour, H.; Boutekrabt, A. Line $\times$ Tester Mating Design Analysis for Grain Yield and Yield Related Traits in Bread Wheat (Triticum aestivum L.). Int. J. Agron. 2013, 9.

54. Ahmad, E.; Akhtar, M.; Badoni, S.; Jaiswal, J.P. Combining ability studies for seed yield related attributes and quality parameters in bread wheat (Triticum aestivum L.). J Genet Genomics Plant Breed. 2017, 1, 21-27.

55. Hama-Amin, T.N.; Towfiq, S.I. Estimation of some genetic parameters using line $\times$ tester analysis of common wheat (Triticum aestivum 1.). Applied Ecology and Environmental Research, 2019, 17, 9735-9752.

56. Delaney, A. Investigating Parental Effects on End-Use Quality in Hard Winter Wheat (Triticum aestivum L.) Hybrids. 2019.

57. Khan, S.A.; Hassan, G. Heritability and correlation studies of yield and yield related traits in bread wheat. Sarhad Journal of Agriculture, 2017, 33, 103-107.

58. Sareen, S.; Bhusal, N.; Singh, G.; Tyagi, B.S.; Tiwari, V.; Singh, G.P.; Sarial, A.K. Genetics of grain yield and its components in wheat under heat stress. Cereal Res. Comm. 2018 46, 448-459. 